\title{
Feasibility and acceptability of a future-oriented empowerment program to prevent substance use and school dropout among school-disengaged youth
}

\author{
Sarah A. Stoddard PhD, RN, Assistant Professor ${ }^{1}$ (D) | Kathryn Hughesdon PhD, RN, \\ Assistant Professor ${ }^{2}$ | Angubeen Khan MPH, Graduate Student Researcher ${ }^{3}$ | \\ Marc A. Zimmerman PhD, Professor ${ }^{4}$
}

${ }^{1}$ Department of Systems, Populations and Leadership, University of Michigan School of Nursing, Ann Arbor, Michigan

${ }^{2}$ School of Nursing, Eastern Michigan University, Ypsilanti, Michigan

${ }^{3}$ California Center for Health Policy Research, University of California, Los Angeles, California

${ }^{4}$ University of Michigan School of Public Health, Ann Arbor, Michigan

\section{Correspondence}

Sarah A. Stoddard, Department of Systems, Populations and Leadership, University of Michigan School of Nursing, 400 North Ingalls Building, Ann Arbor 48109-5482, MI

Email: sastodda@umich.edu

Funding information

This study was supported by a Mentored Scientist Career Development Award (1K01 DA034765, PI: Stoddard) from the National Institute on Drug Abuse and the University of Michigan Office of Research.

\begin{abstract}
Objective: To evaluate the feasibility and acceptability of a health promotion program to prevent school dropout and substance use among middle school-aged youth who display early warning signs of school disengagement.

Intervention: Youth Empowerment Solutions for Positive Futures (YES-PF), an intensive, theoretically driven, 5-week summer enrichment program, aims to prevent school dropout and substance use by promoting youth empowerment, school engagement, and future orientation.

Design and Sample: Using a pre-post-intervention design, we test feasibility and acceptability with 6th and 7 th grade students $(n=43)$ who exhibited early warning signs for school disengagement (e.g., chronic absenteeism) in two school districts.

Measures: Program evaluation components included: (a) program session forms completed by facilitators; (b) post-program interviews with facilitators; (c) post-intervention program evaluation surveys with youth; (d) attendance; and (e) baseline and post-intervention surveys with youth to assess behavioral and psychosocial outcomes. Results: Facilitators routinely delivered core component lesson activities. Acceptability and program satisfaction were evidenced in strong program attendance by youth. Youth participants reported higher levels of leadership efficacy $(p<.05)$ and a greater sense of control over their lives and potential problems $(p<.01)$.

Conclusions: YES-PF was feasible and acceptable to school personnel and youth. Program refinement, based on implementation findings, is discussed.

KEYWORDS

program evaluation, risk prevention, substance use
\end{abstract}

\section{BACKGROUND}

Secondary school dropout is associated with negative health, social, and economic outcomes (Amos, 2009; Russell, 2011). Youth who do not complete secondary school are at increased risk for unhealthy substance use (Maynard, Salas-Wright, \& Vaughn, 2015; McCabe, Teter, Boyd, Wilens, \& Schepis, 2018; Reingle Gonzalez et al., 2016). In addition, youth who drop out of secondary school prior to graduation have the highest prevalence of opioid misuse compared to other youth (McCabe et al., 2018; Schepis, Teter, Mccabe, 2018). 
Early warning signs for school dropout (e.g., chronic absenteeism, course failure) begin during the middle school years (age 11-13, grades 6-8). Chronic absenteeism, course failure, and problem behaviors, in grades 6 through 8 (i.e., middle school) are strong predictors of poor academic outcomes in secondary school (Cohen \& Smerdon, 2009); this includes leaving school prior to graduation (Franklin \& Trouard, 2016; Henry, Tolan, Gorman-Smith, \& Schoeny, 2012; Wang \& Fredricks, 2014). These early indicators of secondary school dropout are also predictors of later alcohol, tobacco, and marijuana use (Henry \& Huizinga, 2007; Henry, Knight, \& Thornberry, 2012; Trenz, Dunne, Zur, \& Latimer, 2015). Yet, while school disengagement can be a risk for substance use, substance use also predicts secondary school non-completion (Kelly et al., 2015). Previous research also suggests that a reciprocal relationship exists between substance use and school disengagement (Thornberry, Lizotte, Krohn, Farnworth, \& Joon Jang, 1991; Wang \& Fredricks, 2014). For example, following a sample of adolescents from 7th through 11th grade, Wang and Fredricks (2014) found changes in substance use were predicted by early levels of engagement in school and, in turn, changes in school engagement were predicted by early substance use. Regardless of directionality, there is a clear relationship between school disengagement and substance use. It is critical to intervene with at-risk students during the middle school years to prevent substance use and poor academic outcomes during the secondary school years; intervening earlier will support graduation later (Balfanz, Herzog, \& Mac Iver, 2007) and prevent potentially lifelong risky substance use.

Although numerous evidence-based universal substance use prevention programs exist, few programs are tailored specifically for a population of middle school-aged students at increased risk for substance use (i.e., students who already exhibit early warning signs for secondary school dropout). Evidence-based selective and indicated substance use prevention programs exist for older students (age 14-18) with risk factors for school dropout (Eggert, Thompson, Herting, Nicholas, \& Dicker, 1994; Sussman, Dent, \& Stacy, 2002); however, we know of none for this higher risk population of middle school-aged students. Indicated programs specific to high-risk secondary school students have been effective in reducing both school dropout and drug use (Sussman et al., 2002), but intervening prior to secondary school-to prevent or delay early substance use initiation-is vital to support a positive trajectory for youth during a critical developmental period.

\section{2 | THEORETICAL UNDERPINNINGS}

Theory and previous research point to the importance of identifying and enhancing individual characteristics that contribute to healthy adolescent development and the prevention of risky behaviors (Hawkins, Catalano, \& Miller, 1992; Kia-Keating, Dowdy, Morgan, \& Noam, 2011; Schwartz et al., 2010). Future orientation, or an individual's thoughts and feelings about the future, is consistently related to less alcohol and drug use, delinquency, and violence (Steiger, Stoddard, \& Pierce, 2017; Stoddard, Heinze, Choe, \& Zimmerman, 2015; Stoddard \& Pierce, 2018; Stoddard, Varela, \& Zimmerman, 2015; Stoddard,
Zimmerman, \& Bauermeister, 2011). Conversely, a negative outlook toward the future is associated with negative outcomes including substance misuse (Bolland, 2003; DuRant, Cadenhead, Pendergrast, \& Slavens, 1994). Future orientation is likely a key mechanism to target for the prevention of school dropout and substance misuse.

Empowerment Theory provides a unique conceptual framework for developing programs to enhance positive youth development. Empowerment theory incorporates the notion that health promotion requires not only that youth develop specific skills and positive assets but also that they become motivated to actively apply these skills and knowledge to become agents of positive change for themselves and in their communities (Zimmerman, 1995, 2000). Empowerment theory focuses on processes to engage individuals in activities that help them develop confidence, skills, and behavioral strategies to achieve self-identified goals (Zimmerman, 1995, 2000). Empowerment interventions have been effective as the basis for violence and drug and alcohol use prevention interventions (Substance Abuse \& Mental Health Services Administration, 2014; Wallerstein \& Bernstein, 1988; Wallerstein \& Martinez, 1994; Zimmerman et al., 2018). We posit that an empowering intervention that helps youth gain confidence, think critically, and take actions to effectively deal with stress, and to set and strive for self-determined goals can foster the development of future orientation, in turn, reducing school disengagement and substance use (see Figure 1).

The purpose of this study is threefold. First, we briefly describe YES-PF and its development. Second, we present the results of an initial study to evaluate the feasibility and acceptability of the curriculum, and preliminary outcomes in a sample of 6th and 7th grader youth. Finally, we discuss how study results were used to inform program refinement.

\section{3 | METHODS}

\section{1 | Study design, context, and sample}

This feasibility study of a new intervention for 6th and 7th grade students who exhibit early warning signs for school dropout employed a pre- and post-test design. Two school districts in the Detroit metropolitan area participated in the study during the summer of 2017. These school districts had lower graduation rates (44\% and 68\%) than the national averages (graduation rates $=85 \%$; National Center for Education Statistics, 2019). The school districts also have high rates of chronic absenteeism, which is another risk factor for high school dropout (Warren, Fazekas, Rennie-Hill, Fancsali, \& Jaffe-Walters, 2011), and a large portion of students (76\% and 61\%) who are eligible for free or reduced price lunch (Michigan Department of Education, 2019). One middle school in each school district served as a study site. In all, 62 6th and 7th grade students who exhibited early warning signs for school dropout in two schools were invited to participate in the study; 43 students participated in the study (mean age $=12.3$ years; $S D=0.77$ ). See Table 1 for demographic characteristics of student participants. Preintervention data were collected on the first day of the intervention; 


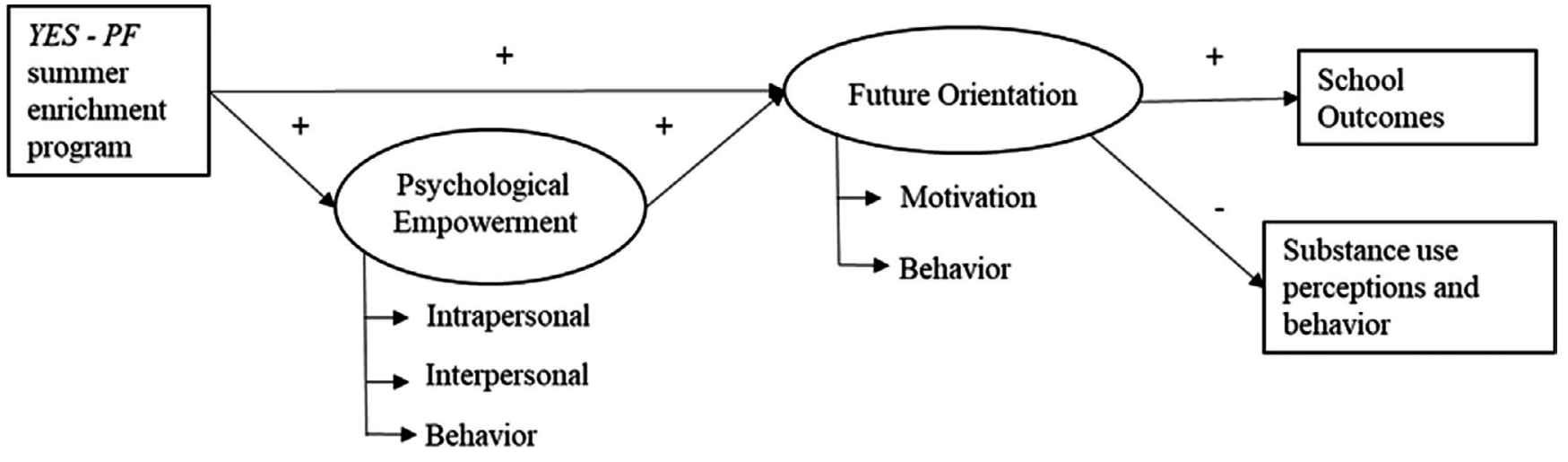

FIGURE 1 Conceptual model

post-intervention data were collected on the last day of the intervention. Program evaluation assessed feasibility and acceptability.

\subsection{The Youth Empowerment Solutions for Positive Futures intervention}

Youth Empowerment Solutions for Positive Futures (YES-PF) is a theoretically driven, intensive 5-week summer enrichment program developed specifically for youth who are at risk for school disengagement and substance use. The program is grounded in the underlying belief that enhancing future orientation through empowerment may be a key intervention strategy to reducing adolescent substance use and school disengagement. YES-PF is an adaptation of Youth Empowerment Solutions (YES), an afterschool violence-prevention program focused on building positive assets, participation in community service events, and connecting youth with adult role models (Zimmerman et al., 2018; Zimmerman, Stewart, Morrel-Samuels, Franzen, \& Reischl, 2011). YES-PF builds on the core empowerment components of YES, but places more emphasis on future orientation and school change.

The YES-PF curriculum was developed through an iterative process that included the research team, frontline staff, and youth. The research team reviewed the original YES curriculum for content and structure. Activities that engaged students in leadership development, community assessment, and project planning were retained, however, with emphasis placed on the school environment. Based on the overarching goal for YES-PF, the theoretical framework, and research on future orientation, the research team revised activities and added new activities to engage youth in identifying personal passions and strengths, goal-setting, and self-representation. The 2017 YES-PF summer program included six units. See Table 2 for description of each unit and program content. Ten core components crosscut the sessions: leadership efficacy, leadership behavior, school engagement, self-esteem, personal passions and strengths, goal-setting, self-representation, mentors, help-seeking, and resource mobilization. Through the lessons and activities, youth master new social skills, identify character strengths, become leaders, work in teams, and plan and implement a school-change project.

\section{4 | PROCEDURES}

School personnel identified 6th and 7th grade students who met one or more of the following inclusion criteria: frequent absenteeism (i.e., missed more than $5 \%$ of instructional time), behavioral issues (e.g., school code of conduct violations such as disruptive classroom behavior, suspension), and poor academic performance (e.g., course

TABLE 1 Demographic characteristics of youth participants $(n=43)$

\begin{tabular}{|ll|}
\hline Sample characteristics & Percent \\
\hline Age $(n=43)$ & \\
\hline 11 & 13.95 \\
\hline 12 & 48.84 \\
\hline 13 & 32.56 \\
\hline 14 & 4.65 \\
\hline Gender ( $n=42)$ & \\
\hline Female & 78.57 \\
\hline Male & 21.43 \\
\hline Race ( $n=36)$ & \\
\hline African-American & 47 \\
\hline White & 33 \\
\hline Mixed & 17 \\
\hline Other & \\
\hline Grade level in upcoming school year & 3 \\
\hline 7th & \\
\hline 8th & 45.95 \\
\hline Baseline substance use (ever used) $(n=41)$ & 54.05 \\
\hline Cigarette & \\
\hline Smokeless tobacco & 0 \\
\hline Alcohol & 0 \\
\hline Binge drink (5 or more drinks in a row) & 5 \\
\hline Marijuana & 0 \\
\hline Inhalants & \\
\hline Other drugs & \\
\hline
\end{tabular}

${ }^{a}$ Other includes Asian and American Indian/Alaskan Native. 


\begin{tabular}{|c|c|c|}
\hline Unit & Title & Session activities \\
\hline 1 & $\begin{array}{l}\text { Youth as school } \\
\text { leaders }\end{array}$ & $\begin{array}{l}\text { Students build group norms and team identification, learn about } \\
\text { youth leadership, leadership styles, and leadership roles, and } \\
\text { identify individual character strengths }\end{array}$ \\
\hline 2 & $\begin{array}{l}\text { Learning about our } \\
\text { school community }\end{array}$ & $\begin{array}{l}\text { Students complete a Photovoice project of their school } \\
\text { environment, identify school risks and assets, and discuss how } \\
\text { the environment influences students' feelings about their future }\end{array}$ \\
\hline 3 & $\begin{array}{l}\text { Improving our } \\
\text { school community }\end{array}$ & $\begin{array}{l}\text { Students brainstorm school improvement projects and the } \\
\text { results of their school assessment }\end{array}$ \\
\hline 4 & $\begin{array}{l}\text { Building } \\
\text { intergenerational } \\
\text { partnerships }\end{array}$ & $\begin{array}{l}\text { Students learn strategies for working with adults; develop } \\
\text { confidence speaking and communicating with adults }\end{array}$ \\
\hline 5 & Planning for change & $\begin{array}{l}\text { Students develop a proposal for their school improvement } \\
\text { project that includes project description and goals, a budget } \\
\text { and a time line. Students plan a meeting with school leaders } \\
\text { and present their school improvement project proposal to } \\
\text { school leaders }\end{array}$ \\
\hline 6 & $\begin{array}{l}\text { Action and } \\
\text { reflection }\end{array}$ & $\begin{array}{l}\text { Students develop project work plans and implement their } \\
\text { school improvement projects. Students learn about } \\
\text { overcoming obstacles to personal and project goals. Students } \\
\text { reflect on individual and group strengths, skills used to } \\
\text { complete their project, and how projects changed their school }\end{array}$ \\
\hline
\end{tabular}

TABLE 22017 YES-PF curriculum content grades less than $70 \%$ in language arts and/or math, and/or behind in grade for age). Families of eligible students were provided with an initial overview of the program by school personnel. Families who expressed interest in enrolling their child in the program received information about the study from a member of the research team. Parent consent and youth assent were obtained. The University of Michigan Health Sciences and Behavioral Sciences IRB approved the study (Approval \#HUM00130834).

All participants attended YES-PF. Student participants attended the program 4 days a week, $4 \mathrm{hr}$ per day, for 5 weeks. Students were divided into small groups (6-10 students; three groups per school district) for many of the activities and for their school change project. A trained facilitator was assigned to each small group.

Participants were given a monetary incentive for program attendance ( $\$ 5$ per day; up to $\$ 125$ total). The incentive was provided in the form of two cash payments, at the end of weeks 2 and 5 . Students who did not complete the full program received a monetary incentive consistent with their attendance. Given the high percentage of students with low economic status in the program, breakfast and lunch were provided each day.

\section{1 | YES-PF facilitator training}

Three staff members in each school district were trained by the Research Team to deliver the YES-PF program. This included four teachers, one social worker (MSW), and one education paraprofessional, all of whom were current employees of the school districts. The training consisted of a full-day workshop to familiarize facilitators with curriculum goals, flow and content, and to practice implementing activities. The Research Team monitored implementation and provided technical assistance to facilitators throughout the program.

\section{2 | Program evaluation and measures}

The evaluation was designed to assess the feasibility and fidelity of the YES-PF implementation; gather information about the acceptability of the program by students and program facilitators; collect recommendations for program modifications; and evaluate relevant short term student outcomes. Program evaluation components included: (a) program session forms completed by facilitators after each session; (b) post-program interviews with facilitators; (c) postintervention program evaluation surveys with youth participants; (d) student attendance forms completed daily by facilitators; and (e) baseline and post-intervention surveys with youth participants to assess behavioral and psychosocial indicators and outcomes based on our intervention conceptual model.

To assess feasibility and fidelity, facilitators completed a program session form after each session to assess coverage of the program core components and session activities completed. Forms were specific to each session; facilitators documented activity completion (yes/no) and described any deviations, adaptations, and/or recommendations for revisions to the activities and/or sessions. After program completion, interviews were conducted with facilitators using open-ended, guiding questions intended to prompt discussion of facilitators and barriers to program implementation and recommendations for program modifications.

Students completed the baseline survey on the first day of the program and the post-intervention survey on the last day of the program. Student baseline and post-intervention surveys were comprised 
TAB LE 3 Description of variables assessed at baseline and post-intervention among student participants

$\begin{array}{llll}\text { No of } & & \text { Internal } \\ \text { Construct } & \text { items } & \text { Sample item } & \text { Response format }\end{array}$

Psychological empowerment

Interpersonal

Self-esteem

3

I take a positive attitude toward

5 -point response $(1=$ Strongly

$\alpha=.75$

Rosenberg Self-esteem myself disagree to 5 = Strongly agree)

Scale, Rosenberg

(1965)

\begin{tabular}{|c|c|c|c|c|c|}
\hline $\begin{array}{l}\text { Leadership } \\
\text { efficacy }\end{array}$ & 3 & I am good at leading groups & $\begin{array}{l}\text { 5-point response }(1=\text { Strongly } \\
\text { disagree to } 5=\text { Strongly agree })\end{array}$ & $\alpha=.64$ & $\begin{array}{l}\text { Zimmerman and } \\
\text { Zahniser (1991) }\end{array}$ \\
\hline Civic efficacy & 3 & $\begin{array}{l}\text { I can be involved to change my } \\
\text { community }\end{array}$ & $\begin{array}{l}\text { 5-point response }(1=\text { Strongly } \\
\text { disagree to } 5=\text { Strongly agree) }\end{array}$ & $\alpha=.68$ & $\begin{array}{l}\text { Zimmerman et al } \\
(2018)\end{array}$ \\
\hline \multicolumn{6}{|l|}{ Interactional } \\
\hline $\begin{array}{l}\text { Adults as } \\
\text { resources }\end{array}$ & 1 & $\begin{array}{l}\text { How many adults (no including } \\
\text { your parents) do you know } \\
\text { who can help solve problems } \\
\text { at your school }\end{array}$ & $\begin{array}{l}5 \text {-point response }(0=\text { None to } \\
4=\text { Four or more })\end{array}$ & N/A & Eisman et al. (201 \\
\hline \multicolumn{6}{|l|}{ Behavioral } \\
\hline $\begin{array}{l}\text { Leadership } \\
\text { behavior }\end{array}$ & 3 & $\begin{array}{l}\text { How often do you serve as a } \\
\text { leader in groups }\end{array}$ & $\begin{array}{l}5 \text {-point response }(0=\text { never to } \\
4=\text { always })\end{array}$ & $\alpha=.82$ & $\begin{array}{r}\text { Zimmerman and } \\
\text { Zahniser (1991) }\end{array}$ \\
\hline
\end{tabular}

Future orientation

Motivation

Perceived control 5 I have a little control over things

over future

that happen to me

4-point response ( $1=$ Agree a lot $\quad \alpha=.87$

Lachman and Weaver

Behavio

Behavior

Future time

$4 \quad$ I finish work that is due

to 4 = Disagree a lot)

(1998)

perspective tomorrow before playing today

4-point response $(1=$ disagree $a \quad \alpha=.76$

Zimbardo and Boyd

School outcomes

\section{School \\ engagement}

School

bonding-beliefs

Academic effort 4

School bonding- $\quad 4$

Enjoyment of

school work

Social support 4 adult who really cares about me at my school

Responsible decision $4 \quad$ I say no to activities that I think

Drug use perceptions and behavior outcomes

$\begin{array}{lll}\text { AOD use } & 6 & \text { I believe I have the ability to } \\ \text { perceived control } & \text { avoid drugs }\end{array}$

Descriptive norms 5 goals

\section{Now think about all the} students in your grade at your school. How many of them do you think drank alcohol sometime in the past month?

Drug use may prevent me from reaching my future goals lot to 4 = agree a lot $)$

(1999)

\begin{tabular}{|c|c|c|}
\hline $\begin{array}{l}\text {-point response ( } 1 \text { = strongly } \\
\text { disagree to } 5=\text { strongly agree) }\end{array}$ & $\alpha=.72$ & $\begin{array}{l}\text { California Department } \\
\text { of Education, } 2004\end{array}$ \\
\hline $\begin{array}{l}\text {-point response ( } 1=\text { strongly } \\
\text { disagree to } 5=\text { strongly agree })\end{array}$ & $\alpha=.95$ & Harris \& Udry (2001) \\
\hline $\begin{array}{l}\text { int response }(1=\text { strongly } \\
\text { agree to } 5=\text { strongly agree })\end{array}$ & $\alpha=.78$ & $\begin{array}{l}\text { Social Skills Rating } \\
\text { Scale, Gresham and } \\
\text { Elliot (1990) }\end{array}$ \\
\hline
\end{tabular}

5-point response $(1=$ strongly $\quad \alpha=.81 \quad$ Harris \& Udry (2001) disagree to 5 = strongly agree)

5-point response ( 1 = strongly $\quad \alpha=.64$ disagree to $5=$ strongly agree)

California Department of Education ( 2004)

5-point response (1 = strongly $\quad \alpha=.74$

Youth Asset Survey, disagree to $5=$ strongly agree)

Oman et al. (2002)

4-point response $(1=$ disagree $a \quad \alpha=.98$

lot to 4 = agree a lot)

Armitage, Armitage,

Conner, Loach, and Willetts (1999)

5-point response $(1=$ none to $\quad \alpha=.96 \quad$ Arthur, Hawkins, $5=$ all)

Pollard, Catalano, and

Baglioni (2002)

4-point response $(1=$ disagree $\mathrm{a} \quad \alpha=.91$

Stoddard and Pierce

lot to 4 = agree $a$ lot)
(2018) 
TABLE 3 (Continued)

\begin{tabular}{|c|c|c|c|c|c|}
\hline Construct & $\begin{array}{l}\text { No of } \\
\text { items }\end{array}$ & Sample item & Response format & $\begin{array}{l}\text { Internal } \\
\text { consistency }\end{array}$ & Reference \\
\hline Behavioral control & 5 & $\begin{array}{l}\text { If you have the opportunity in } \\
\text { the upcoming school year [like } \\
\text { someone offers this to you], } \\
\text { how likely is it you would... Try } \\
\text { an alcoholic beverage? }\end{array}$ & $\begin{array}{l}5 \text {-point response }(1=\text { very likely } \\
\text { to } 5=\text { not at all likely) }\end{array}$ & $\alpha=.91$ & Armitage et al. (1999) \\
\hline
\end{tabular}

of standardized measures selected for established reliability and validity with similar populations of youth (described in detail in Table 3). Following our conceptual model, psychological empowerment includes three components: interpersonal (i.e., how individuals think about themselves within their social contexts and their beliefs about their competence), interactional (i.e., understanding and accessing resources needed to achieve one's goals), and behavioral (i.e., the actions individuals need to know how to use to achieve control over their outcomes) (Zimmerman et al., 2018). Future orientation includes aspects of motivation (i.e., one's values, expectancies about the future, and the belief that events in one's life are controllable) and behavior (i.e., the actions an individual uses to achieve control over their outcomes including goal-setting, planning, and school engagement) (Seginer, 2009).

Student participants completed an anonymous 20 -item post-program evaluation survey to assess program acceptability on the last day of the program. Using a 5-point Likert scale, students reported how much they liked specific program activities ( 1 = "I did not like at all" to 4 = "I liked it very much") and how helpful the program was for building core skills ( 1 = "Not at all helpful" to 5 = "Extremely helpful"). Students also responded to two open-ended questions: (a) the best things about the summer program and (b) what they learned that will help them promote a positive school environment.

\section{3 | Analytic strategy}

Different analytic methods were used based on the data collected for each of the four components of the program evaluation. Response frequencies from program session forms were used to evaluate program fidelity and attendance; responses to open-ended questions about adaptations, deviations, and recommendations were reviewed independently by two research team members to identify key points and themes. Responses to facilitator post-intervention interviews were also reviewed independently by two research team members to identify key points and themes. Response frequencies to youth post-intervention survey items were used to evaluate program acceptability. Responses to student open-ended questions about the YES-PF program were reviewed independently by two research team members to identify themes.

Paired $t$ tests were used to assess for changes in psychological and behavioral indicators. Clinical significance was determined by the $t$ value and confidence intervals for $t$ tests, and by Cohen's $d$ effect size values (0.20 small, 0.50 medium, 0.80 large) (Cohen, 1988).

\section{RESULTS}

\subsection{Feasibility and fidelity}

Data from the program session forms, completed by facilitators ( $n=4)$, indicated that the facilitators routinely delivered core component lesson activities. For Units 1 through 5, facilitators periodically skipped unit opening or closing activities, but many of these activities did not include essential content on core components. Facilitators indicated that they did not complete reflection activities in Unit 6.

Post-program interviews with facilitators focused on facilitators and barriers to program implementation and recommendations for program modifications. Facilitators reported the need to offer students "free-time" breaks during the 4-hr period. Facilitators reported providing students with two 20 -min breaks each day. This routinely resulted in one lunch break and one gym/free-time break each day. Facilitators reported challenges to completing school change programs, and recommended starting the school change project planning earlier in the program. They also reported that students become more invested and engaged in the program during project planning and implementation. One facilitator suggested modifications to the community meeting presentation script (Unit 5). Finally, one facilitator suggested alternative strategies for showcasing the group projects. Facilitators also confirmed that they had difficulty completing reflection activities in Unit 6 as students needed more time to complete the school change projects.

\section{2 | Acceptability by student participants}

Student participants indicated high levels of program acceptability. A majority of the students liked learning about character strengths (83.88\%), leadership (83.79\%), assessing the school community (88.89\%), and planning and completing the school change project (89.93\%). In addition, $86.84 \%$ of participants would recommend the program to a friend. Approximately $80 \%$ of students found the program to be very or extremely helpful for building character strengths and social skills.

Student participants overwhelmingly reported that the best thing about YES-PF was helping their school community and working on the school change projects. Other common themes included teamwork, making friends, having fun, and learning leadership skills. 
For example, one participant stated, "The best things about the youth empowerment program was teaching us the importance of leadership and how much fun you can have working together." For promoting a positive school environment, the most prevalent theme was leadership. Other common themes included respect to others, making the school/community better, and teamwork. For example, one participant stated, "Anyone can be a leader in their own way and EVERYONE has a power to make a difference in their community."

\section{3 | Attendance and retention}

Attendance and retention are common concerns in intervention studies, particularly with a sample of students who were recruited based on early warning signs for school dropout, of which one indicator is chronic absenteeism. In all, 43 students started the program. The majority of the students ( $n=39 ; 90 \%$ ) completed the program and the post-intervention survey. Overall student attendance was very good ( $50 \%$ of students attended every day; $36 \%$ of students missed 1-2 days).

\section{4 | Secondary aims: preliminary outcomes}

After completing the YES-PF program, youth participants reported significantly higher levels of leadership efficacy ( $p=.02 ; d=0.42$ ) and a greater sense of control over their lives and potential problems ( $p=.02 ; d=0.43$ ) (see Table 4). There were no significant changes in substance use perceptions; however, youth participants reported that they would be less likely to try alcohol or drugs if offered in the coming school year ( $p=n . s ., d=0.20)$.

\section{6 | DISCUSSION}

YES-PF is an innovative health promotion program, grounded in empowerment theory, and designed to increase psychological empowerment and future orientation, improve school outcomes, and decrease the acceptability of substance use for youth at risk for school dropout. This is a unique program because few programs are designed to enhance future orientation through a process of fostering psychological empowerment (i.e., confidence, skills, and behavioral strategies to achieve self-identified future goals). Identifying and connecting to future goals is an important developmental task during adolescence, and early adolescence, specifically, may represent a poignant turning point for adolescents' expectations for the future and imbue possible future selves with new and unique content. Identifying obtainable, future-oriented goals foster intrinsic motivation and expectations, which are, in turn, related to behavioral choices that increase the likelihood of achieving those goals (Stoddard \& Pierce, 2018). Providing students with skills prior to the high school transition may help reduce these academic fears and bolster future expectations; in turn, reducing school disengagement and substance use.
Our findings support the feasibility and acceptability of YES-PF. Evaluation results confirmed that facilitators routinely delivered session activities, and that facilitators and youth participants indicated high levels of program acceptability. Facilitators noted the importance of the lesson topics on positive youth outcomes. Program dose was strong as almost $90 \%$ of participants missed fewer than 2 days and 50\% attended every day. This is a strong indicator of youth acceptability and satisfaction with the program because they voted with their feet by staying involved. Youth also reported, however, that they liked the curriculum and the activities of the YES-PF program in self-reported anonymous evaluation forms.

Although not powered to test intervention effects on psychosocial or behavioral outcomes, we found clinically relevant changes in leadership efficacy and in sense of control over their lives and potential problems post-intervention. This is consistent with the goals of empowerment-based interventions, which is to engage youth in activities to help them develop confidence, skills, and behavioral strategies to achieve self-identified goals (Zimmerman, 1995, 2000). In addition, students reported they would be less likely to try alcohol or drugs if offered in the coming school year post-intervention, albeit non-significant with a small, but notable, effect size. Although, even a small effect is remarkable as pressures to use substances increase across adolescence. This is consistent with previous research supporting the relationship between indictors of empowerment (i.e., leadership ability) and substance use intentions (Stoddard et al., n.d.). These post-intervention differences indicate that YES-PF is promising and worthy of further refinement and study.

This study is an example of implementation science in a "real-world" context. The intervention was delivered by trained facilitators (predominately teachers) employed by the school district in the school setting. This is important because it increases the ability to generalize our findings to non-research settings and provides insight into the feasibility, acceptability, and efficacy of the intervention as it would be delivered in the practice setting.

\section{7 | APPLICATION OF RESULTS FOR CURRICULUM REVISIONS}

Implementation data obtained from facilitators through the program session forms and post-program interviews were used to inform the following curricular and implementation revisions:

1. Need for student breaks during the 4-hr period. Facilitators reported that students needed unstructured breaks (e.g., gym time, lunch, etc.) during the 4-hr period. In the revised curriculum, session components are now structured in two 75- to 90-min blocks per day to accommodate a schedule that includes unstructured breaks.

2. Core component session activities. Evaluation results indicated that facilitators reported challenges to completing all session 
TABLE 4 Post-intervention effects of YES-PF on youth outcomes $(N=37)$

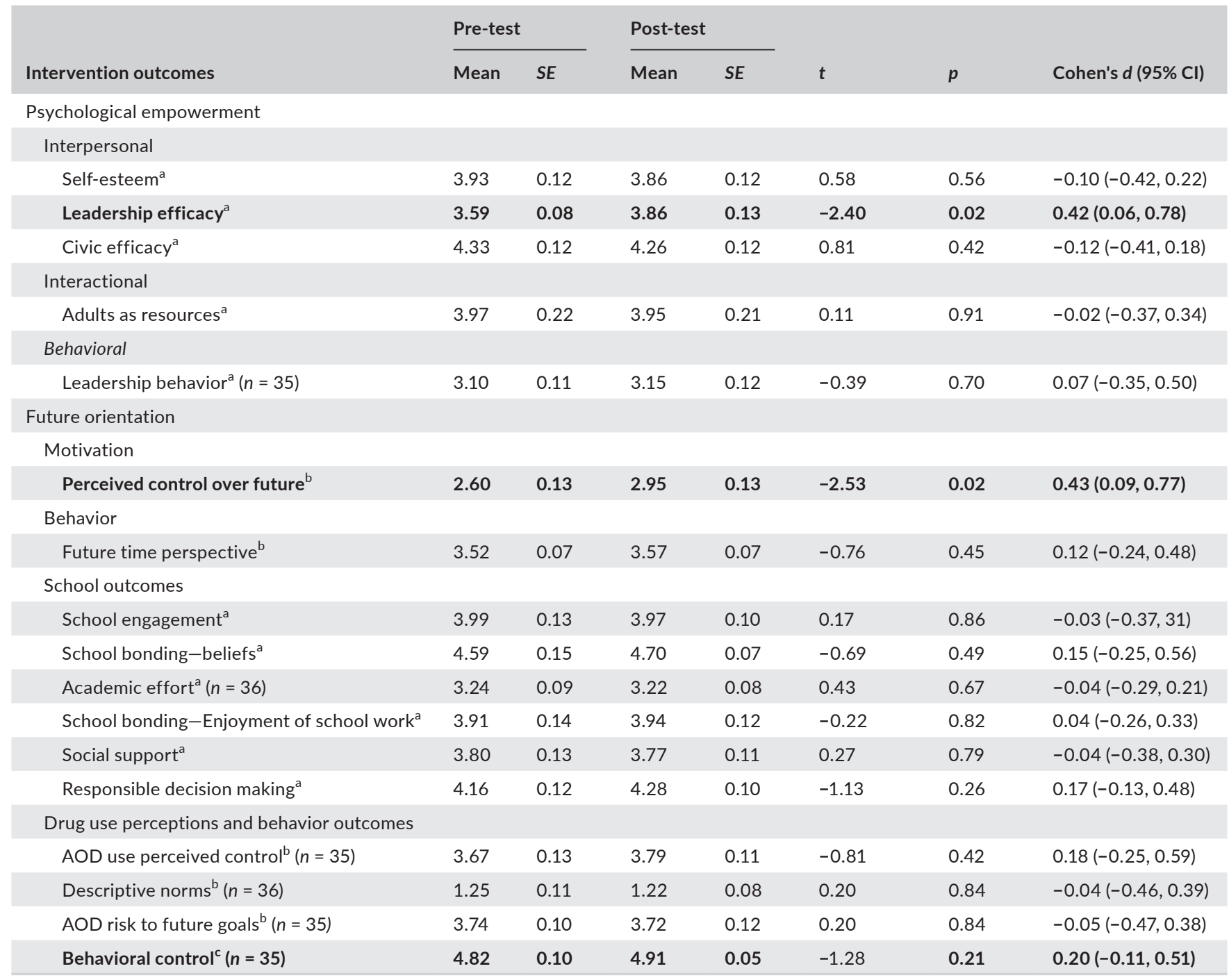

Note: Bold indicates significant results.

Cohen's $d$ : Small effect $=0.2$; medium effect $=0.5$; large effect $=0.8$ (Cohen, 1988) .

a 5 -point Likert scale ( $1=$ strongly disagree to $5=$ strongly agree).

${ }^{\mathrm{b}} 4$-point Likert scale $(1=$ disagree $\mathrm{a}$ lot to $4=$ agree $\mathrm{a}$ lot $)$.

${ }^{\mathrm{c}} 5$-point Likert scale ( $1=$ very likely to $5=$ not at all likely).

components, particularly in Unit 6. Based on facilitator feedback, we revised, shortened, and/or removed some of the session components and restructured the curriculum into five modules to be completed over a minimum of 5 weeks.

3. School change projects. Two themes related to the school change projects emerged from post-program feedback from the facilitators: (a) start school change projects earlier and (b) more time for school change project completion. School change projects were originally introduced in Unit 3. In the revised curriculum, school change projects are now introduced in Unit 2. Also in the revised curriculum, the planning and obtaining of school administrator approval of the school change projects occurs in Unit 3, with time in Units 4 and 5 focused on completing the project. This revised schedule provides 2-3 weeks to complete the school change projects.
Even with changes to the curriculum, considering the facilitator feedback, a 6-week program may be ideal for delivering the intervention in the future to ensure that there is adequate time to cover all core program content.

Finally, based on the preliminary outcomes assessed in the youth pre-post program surveys, we increased content, and place greater emphasis, on positive future orientation throughout the program. Across a variety of sessions, additional content on overcoming both personal and project obstacles was added to sessions to empower youth to recognize ways to overcome obstacles. In addition, across all Units, a greater emphasis was placed on youth reflection about themselves (e.g., passion, strengths), their future goals, and the identification of character strengths used and developed during the school change project. See Table 5 for a description of the revised program units, activities, and core components. 
TAB LE 5 Revised YES-PF curriculum content based on study results and as described in Application of Results for Curriculum Revisions section

\begin{tabular}{|c|c|c|c|}
\hline Unit & Title & Session activities & Core components \\
\hline 1 & Youth as school leaders & $\begin{array}{l}\text { Students build group norms and team identification, and learn } \\
\text { about youth leadership, leadership styles, and leadership } \\
\text { roles. Students identify personal passions, strengths, and } \\
\text { possible selves }\end{array}$ & $\begin{array}{l}\text { Self-esteem; leadership efficacy; } \\
\text { personal passions and strengths; school } \\
\text { engagement; self-representation }\end{array}$ \\
\hline 2 & $\begin{array}{l}\text { Learning about our school } \\
\text { community }\end{array}$ & $\begin{array}{l}\text { Students complete a Photovoice project of their school } \\
\text { environment, identify school risks and assets, and discuss } \\
\text { how the environment influences students' feelings about } \\
\text { their future. Students identify school improvement projects. } \\
\text { Students learn about setting personal and project goals and } \\
\text { timelines, and discuss barriers to meeting goals (e.g., drug use) }\end{array}$ & $\begin{array}{l}\text { Leadership efficacy; school engagement; } \\
\text { resource mobilization; leadership } \\
\text { behavior; self-esteem; goal-setting }\end{array}$ \\
\hline 3 & $\begin{array}{l}\text { Building partnerships and } \\
\text { planning for change }\end{array}$ & $\begin{array}{l}\text { Students learn strategies for working with adults, team } \\
\text { communication, and public speaking. Students develop a } \\
\text { proposal for their school improvement project that includes } \\
\text { project description and goals, a budget and a time line. } \\
\text { Students plan a meeting with school leaders and present } \\
\text { their school improvement project proposal to school leaders }\end{array}$ & $\begin{array}{l}\text { Mentors; help-seeking; resource } \\
\text { mobilization; leadership efficacy; school } \\
\text { engagement; leadership behavior }\end{array}$ \\
\hline 4 & Action-summer projects & $\begin{array}{l}\text { Students develop project work plans and work on their } \\
\text { projects. Students learn about overcoming obstacles to } \\
\text { personal and project goals }\end{array}$ & $\begin{array}{l}\text { Leadership efficacy; school engagement; } \\
\text { leadership behavior; self-esteem }\end{array}$ \\
\hline 5 & Reflection and celebration & $\begin{array}{l}\text { Students complete their projects and reflect on how projects } \\
\text { changed the school. Students reflect on individual and group } \\
\text { strengths and skills used to complete their project }\end{array}$ & $\begin{array}{l}\text { Leadership efficacy; school engagement; } \\
\text { leadership behavior; self-esteem; } \\
\text { goal-setting }\end{array}$ \\
\hline
\end{tabular}

\section{LIMITATIONS}

There are limitations inherent in implementation studies focused on feasibility and acceptability. First, we had only six facilitators in two school districts with significant school dropout. This might limit generalizability of the feasibility assessment, but as the program was intended for school-disengaged students, results may be most useful for similar districts. Similarly, student participant feedback was limited to students attending the two school districts. Second, we did not include fidelity observations, so program adherence was based solely on facilitator self-report. There are several significant limitations with our preliminary outcomes including low power and immediate post-intervention surveys only with no control group, but the results are promising and provide useful preliminary support for the intervention, and provide useful feasibility for measurement process and quality. It is also interesting to note that students ranked several of the measures fairly high at baseline. This may have contributed to fewer significant results, as there was less opportunity to detect change. Yet, it is also notable that despite these issues we did find support in the hypothesized direction for the intervention. A future study that includes a larger sample size, a comparison condition, fidelity observations, and a longer follow-up period is planned to better assess intervention efficacy. Finally, we do not have data on each student's specific warning signs for school disengagement (e.g., school attendance). School personnel identified students based on study inclusion criteria (i.e., the early warning signs). This information will be important in future studies to inform whether intervention efficacy differs by level of student disengagement, for example.
Overall, our findings support the feasibility and acceptability of YES-PF and provided insights to inform future implementation and research of this program. YES-PF addresses an important public health issue, namely, that youth who do not complete secondary school are at increased risk for substance use and other negative outcomes. Intervening early with students who are at increased risk of substance misuse is vital to support a positive trajectory for youth during a critical developmental period, and our findings suggest that a future-oriented, empowerment-based summer enrichment program is a promising approach for prevention and health promotion for at-risk youth.

\section{ORCID}

Sarah A. Stoddard iD https://orcid.org/0000-0001-5825-4159

\section{REFERENCES}

Amos, J. (2009). The consequences of dropping out of high school: Average high school dropout has a negative net fiscal contribution to society of $\$ 5,200$, says new report. Alliance for Excellent Education. Retrieved from http://all4ed.org/articles/the-consequences-of-dropping-outof-high-school-average-high-school-dropouthas-a-negative-net-fiscal-contribution-to-society-of-5200-says-new-report

Armitage, C. J., Armitage, C. J., Conner, M., Loach, J., \& Willetts, D. (1999). Different perceptions of control: Applying an extended theory of planned behavior to legal and illegal drug use. Basic and Applied Social Psychology, 21(4), 301-316. https://doi.org/10.1207/S15324834BASP2104_4

Arthur, M. W., Hawkins, J. D., Pollard, J. A., Catalano, R. F., \& Baglioni, A. J. Jr (2002). Measuring risk and protective factors for use, delinquency, and other adolescent problem behaviors: The Communities That Care Youth Survey. Evaluation Review, 26(6), 575-601. https:// doi.org/10.1177/0193841X0202600601 
Balfanz, R., Herzog, L., \& Mac Iver, D. J. (2007). Preventing student disengagement and keeping students on the graduation path in urban middle-grades schools: Early identification and effective interventions. Educational Psychology, 42, 223-235. https://doi.org/10.1080/00461 520701621079

Bolland, J. M. (2003). Hopelessness and risk behaviour among adolescents living in high-poverty inner-city neighbourhoods. Journal of Adolescence, 26(2), 145-158. https://doi.org/10.1016/S0140-1971(02)00136-7

California Department of Education (2004). California healthy kids survey. Retrieved from http://www.cde.ca.gov/ls/he/at/chks.asp

Cohen, J. (1988). Statistical power analysis for the behavioral sciences (2nd ed.). St. Paul, MN: West Publishing Company.

Cohen, J. S., \& Smerdon, B. A. (2009). Tightening the dropout tourniquet: Easing the transition from middle to high school. Preventing School Failure: Alternative Education for Children and Youth, 53(3), 177-184. https://doi.org/10.3200/PSFL.53.3.177-184

DuRant, R. H., Cadenhead, C., Pendergrast, R. A., Slavens, G., \& Linder, C. W. (1994). Factors associated with the use of violence among urban Black adolescents. American Journal of Public Health, 84(4), 612-617. https://doi.org/10.2105/AJPH.84.4.612

Eggert, L. L., Thompson, E. A., Herting, J. R., Nicholas, L. J., \& Dicker, B. G. (1994). Preventing adolescent drug abuse and high school dropout through an intensive school-based social network development program. American Journal of Health Promotion, 8(3), 202-215.

Eisman, A. B., Zimmerman, M. A., Kruger, D., Reischl, T. M., Miller, A. L., Franzen, S. P., \& Morrel-Samuels, S. (2016). Psychological empowerment among urban youth: Measurement model and associations with youth outcomes. American Journal of Community Psychology, 58(3-4), 410-421. https://doi.org/10.1002/ajcp.12094

Franklin, B. J., \& Trouard, S. B. (2016). Comparing dropout predictors for two state-level panels using Grade 6 and Grade 8 data. The Journal of Educational Research, 109(6), 631-639. https://doi. org/10.1080/00220671.2015.1016601

Gresham, F. M., \& Elliot, S. N. (1990). Social skills rating system (SSRS). Circle Pines, MN: American Guidance Service.

Harris, K. M., \& Udry, J. R. (2001). National Longitudinal Study of Adolescent to Adult Health (Add Health) In School Questionnaire, 1994-2008. Carolina Population Center: University of North Carolina-Chapel Hill.

Hawkins, J. D., Catalano, R. F., \& Miller, J. Y. (1992). Risk and protective factors for alcohol and other drug problems in adolescence and early adulthood: Implications for substance abuse prevention. Psychological Bulletin, 112(1), 64-105. https://doi. org/10.1037/0033-2909.112.1.64

Henry, D. B., Tolan, P. H., Gorman-Smith, D., \& Schoeny, M. E. (2012). Risk and direct protective factors for youth violence: Results from the centers for disease control and prevention's multisite violence prevention project. American Journal of Preventive Medicine, 43(2 Suppl. 1), S67-S75. https://doi.org/10.1016/j.amepre.2012.04.025

Henry, K. L., \& Huizinga, D. H. (2007). Truancy's effect on the onset of drug use among urban adolescents placed at risk. Journal of Adolescent Health, 40(4), 358.e9-358.e17. https://doi.org/10.1016/j. jadohealth.2006.11.138

Henry, K. L., Knight, K. E., \& Thornberry, T. P. (2012). School disengagement as a predictor of dropout, delinquency, and problem substance use during adolescence and early adulthood. Journal of Youth and Adolescence, 41(2), 156-166. https://doi.org/10.1007/ s10964-011-9665-3

Kelly, A. B., Evans-Whipp, T. J., Smith, R., Chan, G. C. K., Toumbourou, J. W. Patton, G. C., ... Catalano, R. F. (2015). A longitudinal study of the association of adolescent polydrug use, alcohol use and high school non-completion. Addiction, 110(4), 627-635. https://doi.org/10.1111/add.12829

Kia-Keating, M., Dowdy, E., Morgan, M. L., \& Noam, G. G. (2011). Protecting and promoting: An integrative conceptual model for healthy development of adolescents. Journal of Adolescent Health, 48(3), 220-228. https://doi.org/10.1016/j.jadohealth.2010.08.006
Lachman, M. E., \& Weaver, S. L. (1998). The sense of control as a moderator of social class differences in health and well-being. Journal of Personality and Social Psychology, 74(3), 763. https://doi. org/10.1037/0022-3514.74.3.763

Light, J. M., Rusby, J. C., Nies, K. M., \& Snijders, T. A. B. (2014). Antisocial behavior trajectories and social victimization within and between school years in early adolescence. Journal of Research on Adolescence, 24(2), 322-336. https://doi.org/10.1111/jora.12055

Maynard, B. R., Salas-Wright, C. P., \& Vaughn, M. G. (2015). High school dropouts in emerging adulthood: Substance use, mental health problems, and crime. Community Mental Health Journal, 51(3), 289-299. https://doi.org/10.1007/s10597-014-9760-5

McCabe, S. E., Teter, C. J., Boyd, C. J., Wilens, T. E., \& Schepis, T. S. (2018). Sources of prescription medication misuse among young adults in the United States: The role of educational status. The Journal of Clinical Psychiatry, 79(2). https://doi.org/10.4088/JCP.17m11958

National Center for Education Statistics (2019). Public High school graduation rates. Retrieved from https://nces.ed.gov/programs/coe/indic ator_coi.asp

Oman, R. F., Vesely, S. K., McLeroy, K., Harris-Wyatt, V., Aspy, C., Rodine, S., \& Marshall, L. (2002). Reliability and validity of the Youth Asset Survey (YAS). Journal of Adolescent Health, 31, 247-255. https://doi. org/10.1016/S1054-139X(02)00363-4

Reingle Gonzalez, J. M., Salas-Wright, C. P., Connell, N. M., Jetelina, K. K., Clipper, S. J., \& Businelle, M. S. (2016). The long-term effects of school dropout and GED attainment on substance use disorders. Drug and Alcohol Dependence, 158, 60-66. https://doi.org/10.1016/j. drugalcdep.2015.11.002

Rosenberg, M. (1965). Rosenberg self-esteem Scale (RSE). In Acceptance and commitment therapy, p. 61. Retrieved from http://www.nou.ueb. ro/psihologie/docs/Psihologie_pozitiva_teste_si_scale.pdf\#page $=61$

Russell, W. (2011). Dropping out: Why students drop out of high school and what can be done about it. Cambridge, MA: Harvard University.

Schepis, T. S., Teter, C. J., \& McCabe, S. E. (2018). Prescription drug use, misuse and related substance use disorder symptoms vary by educational status and attainment in U.S. adolescents and young adults. Drug and Alcohol Dependence, 189, 172-177. https://doi. org/10.1016/J.DRUGALCDEP.2018.05.017

Schwartz, S. J., Phelps, E., Lerner, J. V., Huang, S., Brown, C. H., LewinBizan, S., ... Lerner, R. M. (2010). Promotion as prevention: Positive youth development as protective against tobacco, alcohol, illicit drug, and sex initiation. Applied Developmental Science, 14(4), 197211. https://doi.org/10.1080/10888691.2010.516186

Seginer, R. (2009). Future orientation: Developmental and ecological perspectives. Springer Science \& Business Media.

Steiger, R. M., Stoddard, S. A., \& Pierce, J. (2017). Adolescents' future orientation and nonmedical use of prescription drugs. Addictive Behaviors, 65, 269-274. https://doi.org/10.1016/j.addbeh.2016.08.017

Stoddard, S. A., Heinze, J. E., Choe, D. E., \& Zimmerman, M. A. (2015). Predicting violent behavior: The role of violence exposure and future educational aspirations during adolescence. Journal of Adolescence, 44, 191-203. https://doi.org/10.1016/j.adolescence.2015.07.017

Stoddard, S. A., Heinze, J. E., Eisman, A. B., Cunningham, M., Zimmerman, M. A., \& Rieschl, T. (2019). The relationship between empowerment and substance use intentions during adolescence: The mediating effects of positive future expectations. Presentation, Society for Prevention Science Annual Meeting.

Stoddard, S. A., \& Pierce, J. (2018). Alcohol and marijuana use and intentions among adolescents: The role of the reasoned action approach and positive future orientation. Youth \& Society, 50, 758-779. https:// doi.org/10.1177/0044118X16671610

Stoddard, S. A., Varela, J. J., \& Zimmerman, M. A. (2015). Future expectations, attitude towards violence, and bullying perpetration during early adolescence: A mediation evaluation. Nursing Research, 64(6), 422. 
Stoddard, S. A., Zimmerman, M. A., \& Bauermeister, J. A. (2011). Thinking about the future as a way to succeed in the present: A longitudinal study of future orientation and violent behaviors among African American youth. American Journal of Community Psychology, 48(3-4), 238-246. https://doi.org/10.1007/s10464-010-9383-0

Substance Abuse and Mental Health Services Administration (2014). Lead \& seed. Retrieved from https://www.vfhy.org/sites/default/ files/pdf/Lead_Seed_NREPP.pdf

Sussman, S., Dent, C. W., \& Stacy, A. W. (2002). Project towards no drug abuse: A review of the findings and future directions. American Journal of Health Behavior, 26(5), 354-365.

Thornberry, T. P., Lizotte, A. P., Krohn, M. D., Farnworth, M., \& Joon Jang, S. (1991). Testing interactional theory: An examination of reciprocal causal relationships among family, school, and delinquency. Journal of Criminal Law and Criminology, 82, 3-35.

Trenz, R. C., Dunne, E. M., Zur, J., \& Latimer, W. W. (2015). An investigation of school-related variables as risk and protective factors associated with problematic substance use among vulnerable urban adolescents. Vulnerable Children and Youth Studies, 10(2), 131-140. https://doi.org/10.1080/17450128.2015.1029034

Wallerstein, N., \& Bernstein, E. (1988). Empowerment education: Freire's ideas adapted to health education. Health Education Quarterly, 15(4), 379-394. https://doi.org/10.1177/109019818801500402

Wallerstein, N., \& Martinez, L. (1994). Empowerment evaluation: A case study of an adolescent substance abuse prevention program in New Mexico. Evaluation Practice, 15(2), 131-138. https://doi. org/10.1016/0886-1633(94)90004-3

Warren, C., Fazekas, A., Rennie-Hill, L., Fancsali, C., \& Jaffe-Walters, R. (2011). Final report on the study of promising ninth grade transition strategies: A study of six high schools. Washington: U.S. Department of Education.

Wang, M. T., \& Fredricks, J. A. (2014). The reciprocal links between school engagement, youth problem behaviors, and school dropout during adolescence. Child Development, 85(2), 722-737. https://doi. org/10.1111/cdev.12138

Zimbardo, P. G., \& Boyd, J. N. (1999). Putting time in perspective: A valid, reliable individual-differences metric. Journal of Personality and Social Psychology, 77(6), 1271. https://doi. org/10.1037/0022-3514.77.6.1271

Zimmerman, M. A. (1995). Psychological empowerment: Issues and illustrations. American Journal of Community Psychology, 23(5), 581-599. https://doi.org/10.1007/BF02506983

Zimmerman, M. A. (2000). Empowerment theory. In Handbook of community psychology (pp. 43-63). Boston, MA: Springer.

Zimmerman, M. A., Eisman, A. B., Reischl, T. M., Morrel-Samuels, S., Stoddard, S., Miller, A. L., ... Rupp, L. (2018). Youth empowerment solutions: Evaluation of an after-school program to engage middle school students in community change. Health Education \& Behavior, 45(1). https://doi.org/10.1177/1090198117710491

Zimmerman, M. A., \& Zahniser, J. H. (1991). Refinements of sphere-specific measures of perceived control: Development of a sociopolitical control scale. Journal of Community Psychology, 19(2), 189-204. https ://doi.org/10.1002/1520-6629(199104)19:2<189:AID-JCOP229019 0210>3.0.CO;2-6

How to cite this article: Stoddard SA, Hughesdon K, Khan A, Zimmerman MA. Feasibility and acceptability of a futureoriented empowerment program to prevent substance use and school dropout among school-disengaged youth. Public Health Nurs. 2020;37:251-261. https://doi.org/10.1111/phn.12706 